\title{
Users Versus Non-users: The Impact of Experience on Hotel Guests' Attitudes Towards Service Robots in Hotels
}

\author{
Patrycja Brylska ${ }^{1}$, Cihan Cobanoglu ${ }^{1}\left(\mathbb{D}\right.$, and Seden Dogan $\left.{ }^{2(\bowtie)}\right)([$ \\ ${ }^{1}$ University of South Florida, Tampa, FL, USA \\ brylskap@usf.edu, cihan@cihan.org \\ 2 Ondokuz Mayis University, Samsun, Turkey \\ seden.dogan@omu.edu.tr
}

\begin{abstract}
The use of robotics and artificial intelligence have created a shift in the ways the service-based hospitality and tourism industry can fulfill the needs and wants of consumers that were earlier fulfilled only by humans. Robots have added the automation and self-service experience that play a vital role in the improvements of efficiency, speed, and the overall experience for the guests using technology. While there are many benefits of using robots in the industry, there are also risks associated with the excessive usage of robots on guest experience. As a result of the pros and cons on the topic, it is very important to gather data and analyze the results to further investigate and understand what the outcomes will be for the industry, its employees, and its customers. The purpose of this study is to examine the perceptions of the use of robots in the hotels as perceived by hotel guests who used a service robot and who did not. A selfadministered survey was developed, and 939 usable responses were collected from hotel guests. Factor analysis showed that five factors emerged in the study: Advantages, Attitudes, Disadvantages, Pandemic Related, and Fear. Guests recognize the opportunities that service robots are bringing to their experience while voicing their concerns and fears about the use of them. Findings also showed that there are significant differences between users and non-users.
\end{abstract}

Keywords: Service robots - Guest experience $\cdot$ Artificial intelligence $\cdot$ Customer service

\section{Introduction}

Service robots have been introduced to healthcare, manufacturing, business, and hospitality that are shifting how services are performed. According to Robotics Tomorrow, an online robotics trade magazine, by 2021 the professional service robotic market is predicted to reach $\$ 37$ billion as industries are automating many processes for efficiency and productivity. The purpose of adding these kinds of robots to the hospitality industry is to automate time-consuming and repetitive tasks to accomplish more intellectual functions. The current and future adoption of technological innovations on service automation in hotels, restaurants, airports etc. is being used today yet, there are 
many factors still to be discovered about their use and guest attitudes (Ivanov et al. 2017). The purpose of this study is to examine the attitudes of the hotel guests the use of service robots in the hotels. The second purpose is to determine if the perceptions differ between the guests who have experienced a service robot versus not. The overall objective of this study was to gain knowledge of how customers of the hospitality industry feel about service robots and to further understand their attitudes towards service robots in hotels. In addition, the study aims to suggest a scale for the dimensions for guests' attitudes for service robots in hotels.

\section{Review of Literature}

The newest and most advanced out of all is the addition of service robot usage in the hospitality and tourism industry. Service robots' use ranges from the basic artificially intelligent chatting robots to assist with the service process to complex robot assistants to improve guests' experience. As the number of businesses using service robots grow, it is important to understand what they will bring to the business in relation to the business itself and its customers (Belanche et al. 2020). Robotic automation's rapid growth emerges as software systems use automation, easy process of routine tasks, structured data, and analysis of internal systems that are directly compared with human activities (Aguirre and Rodriguez 2017). The impacts of robotics on businesses and the economy have created tremendous and unstoppable changes with the new way of taking on business opportunities and challenges with using service robots (Dirican 2015). Service robots are automating and changing the current hospitality industry with their advanced technological innovations (Tuomi et al. 2020). The use of robots in hospitality facilities creates a competitive advantage for the companies in the future due to its changing consumer markets and technology growth (Ivanov and Webster 2017). Robots are comprised of different complexity functions and ranges of service which are significant to this service-based industry as the interactions and essential activities of robots differ (Murphy et al. n.d.). For service organizations, it is important to recognize and understand what role robots will play and how it will affect the business, its and customers to ensure satisfaction for all during this emerging trend (Lukanova and Ilieva 2019). Hospitality consumers' acceptance on artificial intelligence provides a more user-friendly system with interactive technology and applicability to the hospitality industry business model (Go et al. 2020). The concept of service robots has been applied into hotel, food and beverage, and meeting and convention segments impacting the corporations, workforce, and customers with its current applications and future trends (Yang et al. 2020). The growing implementation of service robots in hotels provides a unique customer experience like nowhere else by combining human contact and artificial intelligence into one element (Fuentes-Moraleda et al. 2020). Service robots' usage in hotels is reviewed on their performance, process, purpose, trust, and intention with the highest importance for high service performance (Park 2020). Service robots serve as a tool to improve the quality of service offered to travelers as they give an extra reason to comeback to visit for the usage of the advanced technology systems in this fast pace growing technology era (Çakar and Aykol 2020). Similarly, Lee et al. (2021) determined that hotel guests expect high level of technical 
performance and facilitation conditions. Furthermore, the analysis of innovativeness and optimism of technology readiness serve as critical factors in smart hotels as guests enjoy the performance of the robots, their services, and how this technology creates a positive experience for them during their stay (Kim et al. 2020). With the COVID-19 pandemic strategies to flatten the curve many drastic and quick changes have been introduced such as lockdowns, social distancing, stay-at-home orders, travel restrictions which impacted the hospitality industry as a whole. However, the usage of service robots in the hospitality industry serves as a critical factor to both physical and psychological factors of acceptance of the device and its service delivery (Gursoy and Chi 2020). During the COVID-19 pandemic, the service robot usage in hotels has created a positive attitude and responsiveness from customers in comparison to results prior to the pandemic as the fear of human contact and social distancing grew (Kim et al. 2021; Wu et al. 2021). With the increased presence to help manage the spread of COVID-19 and reducing the spread, service robots are able to perform tasks of delivery, sanitization, safety, and security by using their artificial intelligence programming and functions (Zeng et al. 2020).

\subsection{Users Versus Non-users}

The attitudes of customers that used a technology versus customers that did not is a subject of many studies (Chakiso 2019; Izquierdo-Yusta et al. 2015; Seo and Bernsen 2016; Sohail and Al-Jabri 2014; Verkasalo et al. 2010). Sohail and Al-Jabri (2014) investigated the attitudes towards mobile banking between users and non-users. The study found that six out of the seven factors were significantly different between users and non-users. Chakiso (2019) also determined that four out of the five factors that affect attitudes towards mobile banking were significantly different between users and non-users. On the other hand, Verkasalo et al. (2010) investigated how attitudes differ towards smartphone applications between users and non-users. They determined that users have more positive attitudes. Based on the review of literature, we propose the following hypothesis: $\mathrm{H}$ : There is a significant difference in hotel guests' attitudes towards service robots between users and non-users.

\section{Methodology}

\subsection{Sample and Data}

The data for this study was collected with a self-administered online survey using Amazon mTurk, with the total of 1152 responses from hotel guests. The use of mTurk is common in hospitality and tourism technology research (Ali et al. 2021, 2018; Birinci et al. 2018; Esfahani and Ozturk 2019; Nanu et al. 2020; Neto et al. 2020). Researchers should use several techniques to ensure that the responses from MTurk are valid (Cobanoglu et al. 2021). These include asking the same question in the survey twice and comparing the results (i. e. asking the age of the respondent in the beginning of the survey and the date of birth at the end of the survey) and removing the ones that do not match. Out of 1152 responses, 939 usable data was analyzed. 


\subsection{Factor Analysis}

The respondents were asked to evaluate the statements about service robots on a 5point scale $(1=$ Strongly disagree, $5=$ Strongly agree). Before applying the factor analysis, reverse coding was applied when necessary. The statements in the survey were adopted from different academic studies (Bowen and Morosan 2018; Chan and Tung 2019; Chun-Min et al. 2017; Ivanov et al. 2018; Kabadayi et al. 2019; Kattara and El-Said 2013; Papathanassis 2017; Solnet et al. 2019; Sun Tung and Au 2018; Chen et al. 2019; Tussyadiah et al. 2020; Van Pinxteren et al. 2019) except for statements related coronavirus pandemic. Five statements about service robots in pandemic era were created from industrial articles (Frankel 2020; Hultgren 2020; Kahn 2020; Murphy et al. 2020; Reddick 2020; Simon 2020). Reliability measures for the items are presented in Table 1. Overall reliability for 35 items was found as 0.912 .

Exploratory factor analysis results are presented in Table 2. Varimax rotation with Kaiser Normalization was applied and two items that have factor loadings lower than 0.40 have been removed. 34 items out of 35 divided into five factors that explains $55.230 \%$ of the total variance.

Table 1. Reliability measures

\begin{tabular}{l|l|l|l|l}
\hline & $\begin{array}{l}\text { Scale } \\
\text { mean if } \\
\text { item } \\
\text { deleted }\end{array}$ & $\begin{array}{l}\text { Scale } \\
\text { variance if } \\
\text { Item } \\
\text { deleted }\end{array}$ & $\begin{array}{l}\text { Corrected } \\
\text { item-total } \\
\text { correlation }\end{array}$ & $\begin{array}{l}\text { Cronbach's } \\
\text { alpha if item } \\
\text { deleted }\end{array}$ \\
\hline $\begin{array}{l}\text { Robots may learn similarly to } \\
\text { humans allowing better contact }\end{array}$ & 133.97 & 261.956 & 0.623 & 0.907 \\
\hline Robots may be functional & 133.56 & 267.732 & 0.563 & 0.908 \\
\hline Robots may be reliable & 133.67 & 267.370 & 0.567 & 0.908 \\
\hline $\begin{array}{l}\text { Robots may answer basic } \\
\text { questions }\end{array}$ & 133.63 & 267.150 & 0.546 & 0.908 \\
\hline $\begin{array}{l}\text { Robots may be convenient } \\
\text { Robots may be a resource of } \\
\text { knowledge and information }\end{array}$ & 133.56 & 268.145 & 0.567 & 0.908 \\
\hline $\begin{array}{l}\text { Human-robot interactions may } \\
\text { be more efficient }\end{array}$ & 133.63 & 266.373 & 0.614 & 0.908 \\
\hline $\begin{array}{l}\text { Robots may communicate with } \\
\text { guests on basic services }\end{array}$ & 133.58 & 268.206 & 0.570 & 0.908 \\
\hline $\begin{array}{l}\text { Robots may track guest data } \\
\text { for specialized information }\end{array}$ & 133.66 & 267.734 & 0.571 & 0.908 \\
\hline $\begin{array}{l}\text { Robots may reduce any } \\
\text { miscommunication }\end{array}$ & 134.14 & 262.146 & 0.579 & 0.908 \\
\hline $\begin{array}{l}\text { Robots may reduce the time } \\
\text { and resources for basic services } \\
\text { and requests }\end{array}$ & 133.74 & 266.308 & 0.585 & 0.908 \\
\hline
\end{tabular}


Table 1. (continued)

\begin{tabular}{|c|c|c|c|c|}
\hline & $\begin{array}{l}\text { Scale } \\
\text { mean if } \\
\text { item } \\
\text { deleted }\end{array}$ & $\begin{array}{l}\text { Scale } \\
\text { variance if } \\
\text { Item } \\
\text { deleted }\end{array}$ & $\begin{array}{l}\text { Corrected } \\
\text { item-total } \\
\text { correlation }\end{array}$ & $\begin{array}{l}\text { Cronbach's } \\
\text { alpha if item } \\
\text { deleted }\end{array}$ \\
\hline $\begin{array}{l}\text { Robots may save money while } \\
\text { working non-stop }\end{array}$ & 133.66 & 266.46 & 0.576 & 0.908 \\
\hline $\begin{array}{l}\text { Robots may have skills of } \\
\text { advanced recognition and } \\
\text { communication }\end{array}$ & 133.88 & 264.753 & 0.599 & 0.908 \\
\hline $\begin{array}{l}\text { Robots may prevent customer } \\
\text { language barrier }\end{array}$ & 133.71 & 266.367 & 0.553 & 0.908 \\
\hline $\begin{array}{l}\text { Robots may fulfill front line } \\
\text { job functions }\end{array}$ & 133.85 & 265.931 & 0.578 & 0.908 \\
\hline $\begin{array}{l}\text { Robots may sell and upsell } \\
\text { services and products to } \\
\text { customers at the facility }\end{array}$ & 133.91 & 265.331 & 0.559 & 0.908 \\
\hline $\begin{array}{l}\text { Robot innovations may drive } \\
\text { technology and business-based } \\
\text { customers }\end{array}$ & 133.72 & 265.667 & 0.619 & 0.908 \\
\hline $\begin{array}{l}\text { Being served by a robot may } \\
\text { create a safe and healthy } \\
\text { environment }\end{array}$ & 133.91 & 266.178 & 0.594 & 0.908 \\
\hline $\begin{array}{l}\text { Robots may reduce the spread } \\
\text { of the virus }\end{array}$ & 133.74 & 265.206 & 0.572 & 0.908 \\
\hline $\begin{array}{l}\text { Robots may perform the basic } \\
\text { functions in facilities }\end{array}$ & 133.69 & 266.824 & 0.615 & 0.908 \\
\hline $\begin{array}{l}\text { Robots may be safe for our } \\
\text { environment }\end{array}$ & 133.74 & 265.794 & 0.575 & 0.908 \\
\hline $\begin{array}{l}\text { Robots may allow for multiple } \\
\text { language features }\end{array}$ & 133.48 & 269.365 & 0.504 & 0.909 \\
\hline $\begin{array}{l}\text { Robots may not need to be } \\
\text { managed by men-power }\end{array}$ & 134.05 & 265.550 & 0.497 & 0.909 \\
\hline $\begin{array}{l}\text { Robots may be both automated } \\
\text { and efficient }\end{array}$ & 133.73 & 269.479 & 0.559 & 0.909 \\
\hline $\begin{array}{l}\text { Robots may express emotions } \\
\text { and gestures similarly to } \\
\text { humans }\end{array}$ & 134.36 & 262.579 & 0.504 & 0.909 \\
\hline $\begin{array}{l}\text { Robots may replace human } \\
\text { interactions }\end{array}$ & 134.24 & 263.526 & 0.581 & 0.909 \\
\hline $\begin{array}{l}\text { Robots may be easy to clean } \\
\text { and maintain }\end{array}$ & 133.77 & 267.354 & 0.522 & 0.909 \\
\hline $\begin{array}{l}\text { Being served by a robot may } \\
\text { be a scary experience }\end{array}$ & 134.78 & 262.207 & 0.408 & 0.910 \\
\hline
\end{tabular}


Table 1. (continued)

\begin{tabular}{l|l|l|l|l}
\hline & $\begin{array}{l}\text { Scale } \\
\text { mean if } \\
\text { item } \\
\text { deleted }\end{array}$ & $\begin{array}{l}\text { Scale } \\
\text { variance if } \\
\text { Item } \\
\text { deleted }\end{array}$ & $\begin{array}{l}\text { Corrected } \\
\text { item-total } \\
\text { correlation }\end{array}$ & $\begin{array}{l}\text { Cronbach's } \\
\text { alpha if item } \\
\text { deleted }\end{array}$ \\
\hline $\begin{array}{l}\text { Robots may be limited to what } \\
\text { they can do }\end{array}$ & 134.57 & 267.210 & 0.393 & 0.910 \\
\hline Robots may not be helpful & 133.42 & 272.810 & 0.388 & 0.911 \\
\hline $\begin{array}{l}\text { Robots may show concern of } \\
\text { too much technology usage }\end{array}$ & 133.73 & 274.391 & 0.351 & 0.911 \\
\hline $\begin{array}{l}\text { Robots may not have emotions } \\
\text { or fear about the pandemic }\end{array}$ & 133.51 & 273.274 & 0.340 & 0.911 \\
\hline $\begin{array}{l}\text { Robots may replace human } \\
\text { jobs }\end{array}$ & 133.89 & 272.143 & 0.222 & 0.912 \\
\hline $\begin{array}{l}\text { It may be risky to delegate } \\
\text { responsibility to machines }\end{array}$ & 133.55 & 275.369 & 0.231 & 0.912 \\
\hline $\begin{array}{l}\text { Robots may be an expensive } \\
\text { machine }\end{array}$ & 133.57 & 276.263 & 0.237 & 0.912 \\
\hline
\end{tabular}

Table 2. Exploratory factor analysis

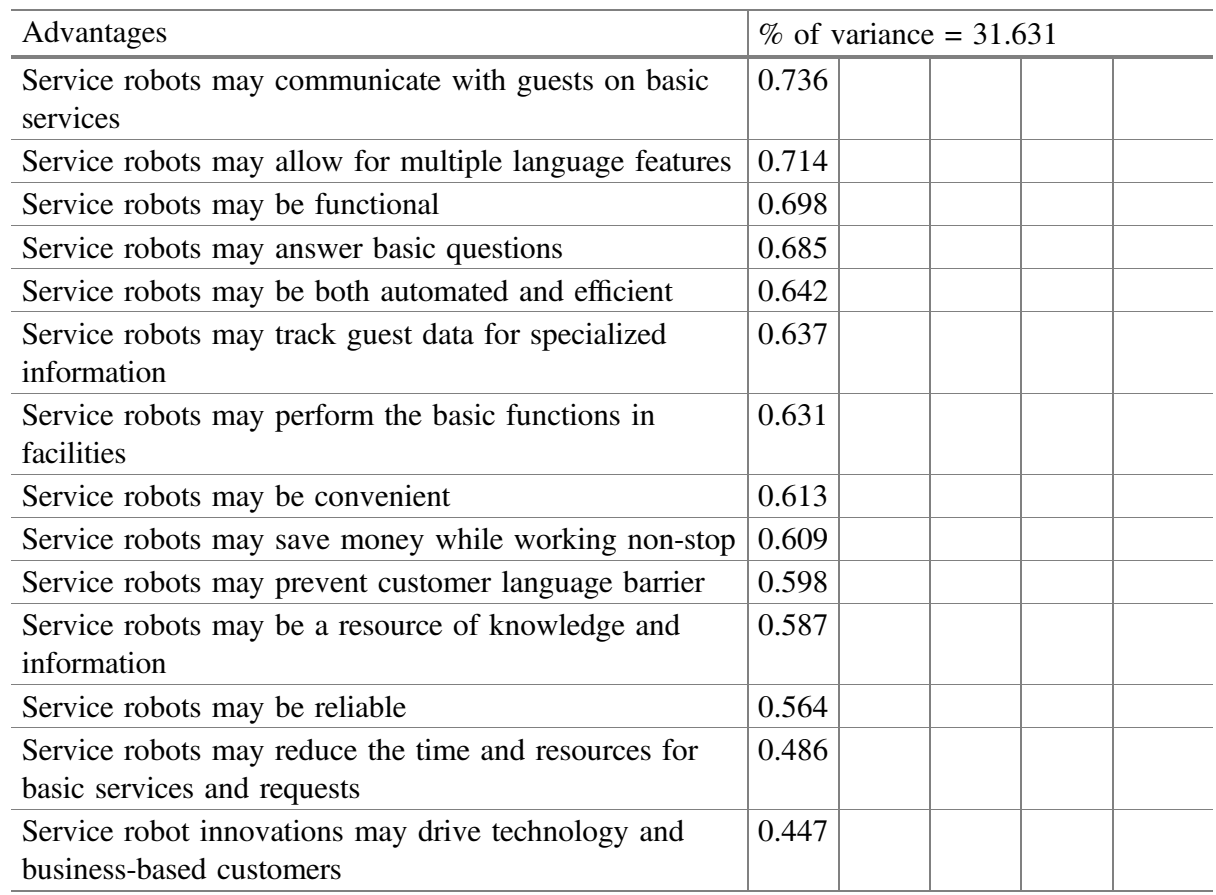


Table 2. (continued)

\begin{tabular}{|c|c|c|c|c|}
\hline Advantages & \multicolumn{4}{|c|}{$\%$ of variance $=31.631$} \\
\hline Attitudes & \multicolumn{4}{|c|}{$\%$ of variance $=10.083$} \\
\hline $\begin{array}{l}\text { Service robots may express emotions and gestures } \\
\text { similarly to humans }\end{array}$ & 0.753 & & & \\
\hline $\begin{array}{l}\text { Service robots may learn similarly to humans allowing } \\
\text { better contact }\end{array}$ & 0.689 & & & \\
\hline Human-robot interactions may be more efficient & 0.635 & & & \\
\hline $\begin{array}{l}\text { Service robots may sell and upsell services and products } \\
\text { to customers at the facility }\end{array}$ & 0.621 & & & \\
\hline Service robots may reduce any miscommunication & 0.620 & & & \\
\hline $\begin{array}{l}\text { Service robots may have skills of advanced recognition } \\
\text { and communication }\end{array}$ & 0.582 & & & \\
\hline Service robots may fulfill front line job functions & 0.494 & & & \\
\hline $\begin{array}{l}\text { Service robots may not need to be managed by men- } \\
\text { power }\end{array}$ & 0.437 & & & \\
\hline Disadvantages & \multicolumn{4}{|c|}{$\%$ of variance $=6.506$} \\
\hline It may be risky to delegate responsibility to machines & & 0.789 & & \\
\hline Service robots may not be helpful & & 0.772 & & \\
\hline $\begin{array}{l}\text { Being served by a service robot may be a scary } \\
\text { experience }\end{array}$ & & 0.743 & & \\
\hline $\begin{array}{l}\text { Service robots may show concern of too much technology } \\
\text { usage }\end{array}$ & & 0.692 & & \\
\hline Service robots may be limited to what they can do & & 0.548 & & \\
\hline Service robots may be an expensive machine & & 0.445 & & \\
\hline Pandemic related & \multicolumn{4}{|c|}{$\%$ of variance $=3.053$} \\
\hline Service robots may be easy to clean and maintain & & & 0.668 & \\
\hline Service robots may be safe for our environment & & & 0.630 & \\
\hline Service robots may reduce the spread of the virus & & & 0.581 & \\
\hline $\begin{array}{l}\text { Being served by a service robot may create a safe and } \\
\text { healthy environment }\end{array}$ & & & 0.484 & \\
\hline Fear & \multicolumn{4}{|c|}{$\%$ of variance $=2.957$} \\
\hline Service robots may replace human jobs & & & & 0.818 \\
\hline Service robots may replace human interactions & & & & 0.717 \\
\hline KMO 0.948 & & & & \\
\hline
\end{tabular}

The first factor was named as Advantages that contains 14 statements related to possible advantages of service robots. The second factor was named as Attitudes that includes eight statements about respondents' attitudes towards service robots. The third factor was named as Disadvantages that contains six statements related to possible disadvantages of service robots. The fourth factor was name as Pandemic Related that has four statements related to service robots' usage during coronavirus pandemic. The last factor was named as Fear that contains two statements about fear towards service robots. 


\subsection{Hypothesis Testing: The Impact of Utilization of Service Robots on Guests' Attitudes.}

An independent $\mathrm{t}$ test was conducted on the factor obtained in the study between the guests who have used or seen a service robot in a hotel versus not. Table 3 shows except for advantages of services robots, all other factors differ between these two groups.

Table 3. Independent sample t test

\begin{tabular}{|c|c|c|c|c|c|c|c|}
\hline & $\begin{array}{l}\text { Experience } \\
\text { with service } \\
\text { robot }\end{array}$ & $\mathrm{n}$ & Mean & sd & $\mathrm{t}$ & F & $\mathrm{p}$ \\
\hline \multirow[t]{2}{*}{ Advantages } & Yes & 593 & 4.17 & 0.630 & \multirow[t]{2}{*}{1.550} & \multirow[t]{2}{*}{9.778} & \multirow[t]{2}{*}{0.122} \\
\hline & No & 346 & 4.11 & 0.502 & & & \\
\hline \multirow[t]{2}{*}{ Attitudes } & Yes & 593 & 3.63 & 0.771 & \multirow[t]{2}{*}{-8.992} & \multirow[t]{2}{*}{33.914} & \multirow[t]{2}{*}{0.000} \\
\hline & No & 346 & 4.02 & 0.560 & & & \\
\hline \multirow[t]{2}{*}{ Disadvantages } & Yes & 593 & 3.36 & 0.787 & \multirow[t]{2}{*}{-13.830} & \multirow[t]{2}{*}{30.441} & \multirow[t]{2}{*}{0.000} \\
\hline & No & 346 & 3.98 & 0.588 & & & \\
\hline \multirow{2}{*}{$\begin{array}{l}\text { Pandemic } \\
\text { Related }\end{array}$} & Yes & 593 & 3.91 & 0.768 & \multirow[t]{2}{*}{-5.512} & \multirow[t]{2}{*}{34.977} & \multirow[t]{2}{*}{0.000} \\
\hline & No & 346 & 4.15 & 0.539 & & & \\
\hline \multirow[t]{2}{*}{ Fear } & Yes & 593 & 3.62 & 1.004 & \multirow[t]{2}{*}{-7.983} & \multirow[t]{2}{*}{46.498} & \multirow[t]{2}{*}{0.000} \\
\hline & No & 346 & 4.07 & 0.714 & & & \\
\hline
\end{tabular}

Table 3 shows that guests who have experience with a service robot or have seen one, have lower level of fear (mean $=3.62)$ versus guests who have zero experience (mean $=4.07$ ). On the other hand, guests who have not used or seen a service robot have more positive attitudes towards service robots (mean $=4.02$ ) and think more positively about service robots' advantages in the pandemic era $($ mean $=4.15)$. Additionally, the guests who have used or seen a service robot think more positively about robots' disadvantages (mean $=3.36$ ). Finally, there is no difference between two groups regarding the advantages of the service robots.

\section{Conclusion}

With the purpose of this study being to identify and examine perceptions of the use of robots in hotels as perceived by hotel guests, the conclusion has resulted in positive attitudes and perceptions towards the use of robots in the hospitality industry. The data gathered and analyzed was separated into 5 categories on a scale from one strongly disagree to five strongly agree. The five categories included: advantages, attitudes, disadvantages, pandemic related, and fear. As the data and results show, the advantages of using robots for a reliable and functional addition to guest experience scored the highest along with the pandemic use of robots for safety and cleanliness which has 
created a new impact on the industry. The attitudes on robots were positive with a few negative aspects of unknowingness of what robots can do and how that will sift the industry. The disadvantages of robots exemplified the worry of the limited functions and services robots can perform and that worry of too much technology usage. Following the disadvantages of robots, fear of job replacement and lack of human interactions were a negative aspect as well. According to the independent sample t test results, the guests who have direct or indirect experience with a service robot more negative attitudes and more negative opinions about usage a robot in pandemic era but think more positively about service robots' disadvantages. Choi et al. (2020) also argued why the hotel guests continually show strong resistance to receive service from a robot. The hotel guests defense the core of the hospitality industry which is human touch. The results also show that using or seeing a service robot in a hotel environment help to reduce fear towards them. Similarly, Zhong et al. (2020) found that the people who watched a video about service robot working in a hotel, showed higher intention to book a room in the hotel. Interestingly, no difference was determined between two groups when it came to the advantages of the robots. This study has several limitations like many others. The first limitation is the sample size. Even though the sample size is suitable to conduct the analyses, larger sample group may provide more generalizable results. The second limitation is the question about the service robot existence in the hotels where the respondent stayed. The authors did not ask whether there was a service robot in the hotel. The third limitation is the ignorance of the respondents who have not experience with a service robot. The authors assumed that the respondents who had zero experience with a service robot might have enough knowledge about it to complete the questionnaire. Despite some negative aspects of robots in the industry, many positive aspects and advantages arise from the study exemplifying the unique and innovative technological advancements robots can bring to the industry. The efficiency, convenience, information, experiences, features, and interactions will all create a robotic experience like no other for the industry and its guests. The perceptions of the use of robots in hotels as perceived by hotel guests is very positive with exciting innovative experiences. Previous studies mainly focused to answer the similar questions, but sample of the studies mostly have not used or seen a service robot before. More research in the hospitality context is needed with the participants who have experienced with a service robot to obtain more detailed insights. The results showed that there are significant differences between users and non-users of service robots in hotels. There is more research needed in this area to understand how the use of a service robot influences the attitudes and behaviors of customers.

\section{References}

Aguirre S, Rodriguez A (2017) Automation of a business process using robotic process automation (RPA): a case study. In: Figueroa-García JC, López-Santana ER, Villa-Ramírez JL, Ferro-Escobar R (eds) WEA 2017, vol 742. CCIS. Springer, Cham, pp 65-71. https://doi. org/10.1007/978-3-319-66963-2_7 
Ali F, Terrah A, Wu C, Ali L, Wu H (2021) Antecedents and consequences of user engagement in smartphone travel apps. J Hosp Tour Technol 12(2):355-371. https://doi.org/10.1108/ JHTT-09-2020-0221

Ali L, Yee WF, Imm NS, Akhtar MS (2018) Price fairness, guest emotions, satisfaction, and behavioral intentions in peer to peer accommodation sector. J Glob Bus Insights 3(2):41-51

Belanche D, Casaló LV, Flavián C (2020) Frontline robots in tourism and hospitality: service enhancement or cost reduction? Electron Mark 31(3):477-492. https://doi.org/10.1007/ s12525-020-00432-5

Birinci H, Berezina K, Cobanoglu C (2018) Comparing customer perceptions of hotel and peerto-peer accommodation advantages and disadvantages. Int J Contemp Hosp Manag 30 (2):1190-1210. https://doi.org/10.1108/IJCHM-09-2016-0506

Bowen J, Morosan C (2018) Beware hospitality industry: the robots are coming. Worldw Hosp Tour Themes 10(6):726-733. https://doi-org.ezproxy.lib.usf.edu/10.1108/WHATT-07-20180045

Cakar K, Aykol S (2020) Understanding travellers' reactions to robotic services: a multiple case study approach of robotic hotels. J Hosp Tour Technol. ahead-of-print (ahead-of-print). https://doi.org/10.1108/JHTT-01-2020-0015

Chan APH, Tung VWS (2019) Examining the effects of robotic service on brand experience: the moderating role of hotel segment. J Travel Tour Mark 36(4):458

Chakiso CB (2019) Factors affecting attitudes towards adoption of mobile banking: users and non-users perspectives. EMAJ Emerg Mark J 9(1):54-62

Chen TF, Tan TF, Chen LC, Lai PC, Chung PL (2019) R-tourism: applications and Incorporation of robotics and service automation in tourism and hospitality. Int J E-Educ, e-Bus, e-Manag eLearn 9(2): 138

Choi Y, Choi M, Oh M, Kim S (2020) Service robots in hotels: understanding the service quality perceptions of human-robot interaction. J Hosp Mark Manag 29(6):613-635. https://doi.org/ 10.1080/19368623.2020.1703871

Chun-Min K, Li-Cheng C, Chin-Yao T (2017) Investigating an innovative service with hospitality robots. Int J Contemp Hosp Manag 29(5):1305-1321. https://doi.org/10.1108/ IJCHM-08-2015-0414

Cobanoglu C, Cavusoglu M, Turktarhan G (2021) A beginner's guide and best practices for using crowdsourcing platforms for survey research: the case of amazon mechanical turk (MTurk). J Glob Bus Insights 6(1):92-97

Dirican C (2015) The impacts of robotics, artificial intelligence on business and economics. Procedia Soc Behav Sci 195:564-573. https://doi.org/10.1016/j.sbspro.2015.06.134

Esfahani SS, Ozturk AB (2019) The influence of individual differences on NFC-based mobile payment adoption in the restaurant industry. J Hosp Tour Technol 10(2):219-232. https://doi. org/10.1108/JHTT-01-2018-0009

Frankel M (2020) Robots are playing many roles in the coronavirus crisis and offering lessons for future disasters. https://theconversation.com/robots-are-playing-many-roles-in-thecoronavirus-crisis-and-offering-lessons-for-future-disasters- 135527

Fuentes-Moraleda L, Díaz-Pérez P, Orea-Giner A, Muñoz- Mazón A, Villacé-Molinero T (2020) Interaction between hotel service robots and humans: a hotel-specific service robot acceptance model (sRAM). Tour Manag Perspect 36:100751. https://doi.org/10.1016/j.tmp.2020.100751

Go H, Kang M, Suh SC (2020) Machine learning of robots in tourism and hospitality: Interactive technology acceptance model (iTAM) - cutting edge. Tour Rev 75(4):625-636. https://doi. org/10.1108/TR-02-2019-0062

Gursoy D, Chi CG (2020) Effects of COVID-19 pandemic on hospitality industry: Review of the current situations and a research agenda. J Hosp Mark Manag 29(5):527-529. https://doi.org/ $10.1080 / 19368623.2020 .1788231$ 
Hultgren O (2020) Robots are taking over the COVID-19 clean-up job. https://cse.umn.edu/ college/feature-stories/robots-are-taking-over-covid-19-clean-job

Ivanov S, Webster C, Seyyedi P (2018) Consumers' attitudes towards the introduction of robots in accommodation establishments. Tourism (13327461) 66(3):302

Ivanov SH, Webster C (2017) designing robot-friendly hospitality facilities (SSRN scholarly paper ID 3053206). Soc Sci Res Netw. https://papers.ssrn.com/abstract=3053206

Ivanov SH, Webster C, Berezina K (2017) Adoption of robots and service automation by tourism and hospitality companies (SSRN scholarly paper ID 2964308). Soc Sci Res Netw. https:// papers.ssrn.com/abstract $=2964308$

Izquierdo-Yusta A, Olarte-Pascual C, Reinares-Lara E (2015) Attitudes toward mobile advertising among users versus non-users of the mobile Internet. Telemat Inform 32 (2):355-366

Kabadayi S, Ali F, Choi H, Joosten H, Lu C (2019) Smart service experience in hospitality and tourism services: a conceptualization and future research agenda. J Serv Manag 30(3):326348. https://doi-org.ezproxy.lib.usf.edu/10.1108/JOSM-11-2018-0377

Kattara HS, El-Said OA (2013) Customers' preferences for new technology-based self-services versus human interaction services in hotels. Tour Hosp Res 13(2):67

Kahn, J.: Cleaning robots have their moment in the fight against COVID-19 (2020). https:// fortune.com/2020/06/01/cleaning-robots-sales-soar-coronavirus-pandemic/

Kim JJ, Lee MJ, Han H (2020) Smart hotels and sustainable consumer behavior: testing the effect of perceived performance, attitude, and technology readiness on word-of-mouth. Int J Environ Res Public Health 17(20):7455. https://doi.org/10.3390/ijerph17207455

Kim S (Sam), Kim J, Badu-Baiden F, Giroux M, Choi Y (2021) Preference for robot service or human service in hotels? Impacts of the COVID-19 pandemic. Int J Hosp Manag 93:102795. https://doi.org/10.1016/j.ijhm.2020.102795

Lee Y, Lee S, Kim D-Y (2021) Exploring hotel guests' perception of using robot assistants. Tour Manag Perspect 37:100781. https://doi.org/10.1016/j.tmp.2020.100781

Lukanova G, Ilieva G (2019) Robots, artificial intelligence, and service automation in hotels. In: Ivanov S, Webster C (eds) Robots, artificial intelligence, and service automation in travel, tourism and hospitality. Emerald Publishing Limited, pp 157-183. https://doi.org/10.1108/ 978-1-78756-687-320191009

Murphy RR, Adams J, Gandudi VBM (2020) How robots are on the frontlines in the battle against COVID-19. https://www.smithsonianmag.com/innovation/how-robots-are-on-frontlines-battle-against-covid-19-180974720/

Murphy J, Hofacker CF, Gretzel U (n.d.) Robots in hospitality and tourism: a research agenda 5

Nanu L, Ali F, Berezina K, Cobanoglu C (2020) The effect of lobby design on booking intentions: an intergenerational examination. Int J Hosp Manag 89. https://doi.org/10.1016/j. ijhm.2020.102530

Neto AP, da Silva EAL, Ferreira LVF, Araújo JFR (2020) Discovering the sustainable hotel brand personality on TripAdvisor. J Hosp Tour Technol 11(2):241-254. https://doi.org/10. 1108/JHTT-05-2019-0076

Papathanassis A (2017) R-tourism: introducing the potential impact of robotics and service automation in tourism. Ovidius Univ Ann Econ Sci Ser 1:211

Park S (2020) Multifaceted trust in tourism service robots. Ann Tour Res 81:102888. https://doi. org/10.1016/j.annals.2020.102888

Van Pinxteren MME, Wetzels RWH, Rüger J, Pluymaekers M, Wetzels M (2019) Trust in humanoid robots: implications for services marketing. J Serv Mark 33(4):507

Reddick R (2020) How coronavirus set the stage for a techno-future with robots and AI. https:// theconversation.com/how-coronavirus-set-the-stage-for-a-techno-future-with-robots-and-ai136475 
Seo D, Bernsen M (2016) Comparing attitudes toward e-government of non-users versus users in a rural and urban municipality. Gov Inf Q 33(2):270-282

Simon M (2020) The COVID-19 pandemic is a crisis that robots were built for. https://www. wired.com/story/covid-19-pandemic-robots/

Sohail MS, Al-Jabri IM (2014) Attitudes towards mobile banking: are there any differences between users and non-users? Behav Inf Technol 33(4):335-344

Solnet D, Mahesh S, Ford CR, Golubovskaya M, Kang HJ, Hancer M (2019) Leveraging human touch in service interactions: lessons from hospitality. J Serv Manag 30(3):392-409. https:// doi-org.ezproxy.lib.usf.edu/10.1108/JOSM-12-2018-0380

Sun Tung VW, Au N (2018) Exploring customer experiences with robotics in hospitality. Int J Contemp Hosp Manag 30(7):2680

Tuomi A, Tussyadiah IP, Stienmetz J (2020) Applications and implications of service robots in hospitality. Cornell Hosp Q, 1938965520923961

Tussyadiah IP, Zach FJ, Wang J (2020) Do travelers trust intelligent service robots? Ann Tour Res 81. https://doiorg.ezproxy.lib.usf.edu/10.1016/j.annals.2020.102886

Verkasalo H, López-Nicolás C, Molina-Castillo FJ, Bouwman H (2010) Analysis of users and non-users of smartphone applications. Telemat Inform 27(3):242-255

Wu J, Zhang X, Zhu Y, Yu-Buck GF (2021) Get close to the robot: the effect of risk perception of COVID-19 pandemic on customer-robot engagement. Int J Environ Public Health 18 (12):1-17. https://doi.org/10.3390/ijerph18126314

Yang L, Henthorne TL, George B (2020) Artificial intelligence and robotics technology in the hospitality industry: current applications and future trends. In: George B, Paul J (eds) Digital transformation in business and society. Springer, Cham, pp 211-228. https://doi.org/10.1007/ 978-3-030-08277-2_13

Zeng Z, Chen P-J, Lew AA (2020) From high-touch to high-tech: COVID-19 drives robotics adoption. Tour Geogr 22(3):724-734. https://doi.org/10.1080/14616688.2020.1762118

Zhong L, Sun S, Law R, Zhang X (2020) Impact of robot hotel service on consumers' purchase intention: a control experiment. Asia Pac J Tour Res 25(7):780-798. https://doi.org/10.1080/ 10941665.2020.1726421

Open Access This chapter is licensed under the terms of the Creative Commons Attribution 4.0 International License (http://creativecommons.org/licenses/by/4.0/), which permits use, sharing, adaptation, distribution and reproduction in any medium or format, as long as you give appropriate credit to the original author(s) and the source, provide a link to the Creative Commons license and indicate if changes were made.

The images or other third party material in this chapter are included in the chapter's Creative Commons license, unless indicated otherwise in a credit line to the material. If material is not included in the chapter's Creative Commons license and your intended use is not permitted by statutory regulation or exceeds the permitted use, you will need to obtain permission directly from the copyright holder.

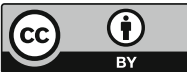

